\title{
Щодо управління спроможностями забезпечення потреб збройних сил боєприпасами
}

\section{Євгеній Косарецький * 1 А; Анатолій Павліковський 2 А; Костянтин Гунбін ${ }^{3}$ в; Олег Бондаренко ${ }^{4}$; ; Михайло Лаврук 5 А \\ А Національний університет оборони України імені Івана Черняховського, пр-т Повітрофлотський, 28, м. Київ, 03049, Україна

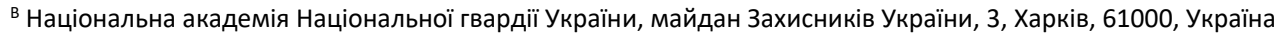 с Інститут державного управління та наукових досліджень з цивільного захисту, Київ, 02000, Україна}

Received: June 1, 2021 | Revised: June 19, 2021 | Accepted: June 30, 2021

DOI: $10.33445 /$ sds.2021.11.3.9

\begin{abstract}
Анотація
У статті здійснено аналіз завдань, що виконуються Збройними Силами України та заходів забезпечення боєприпасам Збройних Сил України в мирний і в воєнний час. Метою дослідження $\epsilon$ аналіз відповідності між завданнями, що вирішують Збройні Сили України, та запасами боєприпасів, що призначені для забезпечення військ під час виконання ними завдань. На підставі систематизації літературних джерел та підходів до вирішення проблеми забезпечення Збройних Сил України боєприпасами з'ясовано, що за будь-яких умов обстановки Збройні Сили повинні забезпечити стримування збройної агресії проти України та надати їй відсіч, здійснювати охорону повітряного простору держави та підводного простору у межах територіального моря України у випадках, визначених законодавством України, а також брати участь у заходах, спрямованих на боротьбу 3 тероризмом. Методичним інструментарієм проведеного дослідження стали аналіз, синтез, декомпозиція, досвід ведення бойових дій на Сході України. У дослідженні розглянуті процеси набуття потрібних спроможностей забезпечення боєприпасами Збройних Сил України в мирний і в воєнний час. Запропоновані показники та критерії оцінки ефективності спроможностей забезпечення потреб збройних Сил боєприпасами. Запропонована інформаційно-логічна модель процесу забезпечення Збройних Сил боєприпасами в мирний час і в воєнний час, яка дає наглядне уявлення співвідношення завдань, що виконуються Збройними Силами України та заходів забезпечення боєприпасам Збройних Сил України в мирний і в воєнний час. Модель доцільно застосовувати у підтримці прийняття рішень під час організації заходів забезпечення Збройних Сил боєприпасами. Результати проведеного дослідження можуть бути корисними для науковців та управлінців, які вивчають проблематику всебічного забезпечення боєприпасами Збройних Сил України під час проведення ними операцій зі стримування збройної агресії.
\end{abstract}

Ключові слова: Збройні Сили, спроможність забезпечення, інформаційно-логічна модель, мирний час, воєнний час, боєприпаси, забезпечення.

\section{Постановка проблеми}

На сьогодні в забезпеченні Збройних Сил спостерігаються дві тенденції: з одного боку, безперервно зростають потреби військ у боєприпасах, з іншого - ускладняються умови й знижуються можливості держави щодо їх задоволення. В цих умовах значно зростає роль виробництва i накопичення для Збройних Сил боєприпасів, які у початковий

\footnotetext{
1 *Corresponding author: ад'юнкт, e-mail: geka1982@i.ua, ORCID: 0000-0001-9601-8544

2 кандидат військових наук, доцент, начальник Центру воєнно-стратегічних досліджень, e-mail: geka1982@i.ua, ORCID: 0000-0002-0637-368X

${ }^{3}$ кандидат військових наук, доцент, доцент кафедри, e-mail: hunbinkonstantin65@gmail.com

${ }^{4}$ кандидат військових наук, доцент, доцент кафедри, e-mail: dinamo_kiev7@ukr.net, ORCID: 0000-0001-5360-0120

${ }^{5}$ старший викладач кафедри, e-mail: tkachivan9@gmail.com
} 
період воєнного стану $є$ єдиним джерелом задоволення потреб військ (сил) а у подальших бойових діях потребують належного та своєчасного поповнення.

Відповідно до вимог Конституції України, законів України “Про оборону України" та “Про Збройні Сили України” на Збройні Сили України покладені завдання щодо: оборони держави, захисту ії суверенітету, територіальної цілісності та недоторканності. Завдання Збройних Сил України у мирний час та особливий період визначаються також i іншими законами України та нормативноправовими актами. Зміст завдань Збройних Сил України на особливий період, зокрема на стратегічному рівні, визначається у Стратегічному плані застосування Збройних
Сил України, на оперативному рівні - в оперативних планах застосування військ (сил). Збройні Сили України за будь-яких умов обстановки повинні забезпечити стримування збройної агресії проти України та надати їй відсіч, здійснювати охорону повітряного простору держави та підводного простору у межах територіального моря України у випадках, визначених законодавством України, а також брати участь у заходах, спрямованих на боротьбу 3 тероризмом. Якісне виконання цих завдань потребує належного забезпечення боєприпасами. Вирішення цієї вимоги доцільно проводити в межах заходів оборонного планування на основі спроможностей, яке активно впроваджується в Збройних Силах України.

\section{Аналіз останніх досліджень та публікацій}

Відомо, що “Концепція планування на основі спроможностей визнає взаємозалежність сил і засобів, доктрин, організації та підтримки в забезпеченні обороноздатності, а також необхідність вивчення варіантів і компромісів між існуючими та необхідними спроможностями, з огляду на ефективність, ціну та ризики, з тим щоб визначити оптимальні інвестиції в розвиток сил" [1].

Міністерство оборони США запровадило універсальне визначення "спроможності" [2], а саме спроможності - це "здатність по досягненню необхідного результату, визначеного критеріями та умовами, за допомогою комбінації сил і засобів, а також методів і способів їх застосування для виконання поставлених завдань".

У Рекомендаціях з оборонного планування на основі спроможностей в Міністерстві оборони України та Збройних Силах України 12 червня 2017 року було затверджено Міністром оборони України, в [3] деталізується це поняття як спроможність (оперативна, бойова, спеціальна) - це здатність структурної одиниці (елемента) збройних сил (сил оборони) або сукупності сил і засобів виконувати певні завдання (забезпечувати реалізацію визначених військових цілей) за певних умов обстановки, ресурсного забезпечення та відповідно до встановлених стандартів.

У [4] за результатами аналізу вітчизняного та зарубіжного досвіду оборонного планування та 3 урахуванням потреб реформування сектору безпеки і оборони України наведено погляди на особливості оборонного планування на основі спроможностей та перспективи його впровадження у процес розвитку сил оборони держави.

У публікаціях $[5,6]$ відмічається, що “Цей метод [метод оборонного планування на основі спроможностей. - Авт.] включає функціональний аналіз усіх вимог до існуючих та необхідних спроможностей. Спроможності визначаються на основі задач, що потребують вирішення... Після визначення необхідної кількості спроможностей вибираються найбільш ефективні з точки зору витрат варіанти задоволення вимог для виконання необхідних задач".

Виходячи 3 наведених визначень слід відмітити, що особливої уваги в питаннях впровадження оборонного планування на основі спроможностей потребують 
функціональний аналіз усіх вимог до існуючих та необхідних спроможностей та визначення взаємозалежності сил і засобів. Забезпечення Збройних Сил боєприпасами, як важливих засобів ведення сучасних війн, теж підлягає плануванню на основі спроможностей.

Для досягнення необхідного результату під час виконання завдань у Збройних Силах України створюються необхідні запаси боєприпасів. Збройні Сили України мають право застосовувати і використовувати запаси боєприпасів встановленим порядком 3 подальшим їх поповненням. Основний спосіб визначення обсягів запасів боєприпасів - їх розрахунок з огляду на потребу в автономності дій військ упродовж визначеного часу [7]. певна їх кількість, яка призначена для задоволення потреби військ (сил) i яку утримують в органах матеріально-технічного забезпечення (арсеналах, базах, складах), а також безпосередньо в підрозділах (при зброї, на кораблях). Запаси боєприпасів за призначенням поділяють на непорушні запаси та запаси поточного забезпечення.

Запаси поточного забезпечення - це запаси, які призначені для забезпечення військ (сил) у разі переведення Збройних Сил
Під запасами боєприпасів розуміється

3 мирного на воєнний час, оперативного розгортання (перегрупування), під час проведення бойового злагодження та формування резервів.

Непорушні запаси - запаси, які призначені для проведення операцій Збройними Силами України відповідно до визначеної системи операцій в особливий період.

\section{3 метою здійснення безперервного} забезпечення військ (сил) та зменшення втрат створюваних непорушних запасів боєприпасів проводиться їх ешелонування - розподіл запасів боєприпасів за рівнями (ланками) підпорядкованості військ (сил) та (чи) місцями утримання, при цьому запаси боєприпасів поділяються на види: військові, оперативні та стратегічні.

Розрахунок обсягів запасів боєприпасів доцільно проводити з урахуванням стратегічного розгортання та застосування Збройних Сил України за ситуацією, відповідно до якої обсяги запасів боєприпасів повинні бути найбільшими. Маючи запаси боєприпасів у таких обсягах, можна виконувати завдання стосовно будь-якої 3 решти ситуацій. При цьому, запаси боєприпасів повинні мати такий обсяг, який би відповідав потребі військ (сил) під час визначеного періоду забезпечення.

\section{Постановка завдання}

Метою статті $\epsilon$ проведення аналізу відповідності між завданнями, що вирішують Збройні Сили України, та запасами

боєприпасів, що призначені для забезпечення військ під час виконання їх завдань.

\section{Виклад основного матеріалу}

Для спрощення проведення аналізу відповідності між завданнями, що вирішують Збройні Сили України, та заходами щодо забезпечення потреб Збройних Сил боєприпасами в мирний час і в воєнний час, пропонується використовувати інформаційно-логічну модель процесу забезпечення потреб збройних Сил у боєприпасах, яка відображена у таблиці. 1.

Інформаційно-логічна модель являє собою таблицю, зміст якої відображає рішення, що приймаються у системі забезпечення боєприпасами стосовно створення певних видів запасів боєприпасів та їх відповідності завданням Збройних Сил.

у мирний час у Збройних Силах відбувається уточнення завдань і функцій, розвиток, підготовка і підтримання на належному рівні боєздатності, планування застосування, бойова підготовка.

В той же час відбувається забезпечення боєприпасами, їх поступове оновлення, утилізація.

В особливий період під час стратегічного 
розгортання Збройних Сил відбувається доукомплектування військ до штатів воєнного часу, проводиться бойове злагодження під час якого витрачається певна кількість боєприпасів та здійснюється. В той же час відбувається поповнення військових, оперативних і стратегічних запасів боєприпасів до визначених норм. Крім цього, у період стратегічного розгортання Збройних Сил (час мобілізації) відбувається нарощування самостійного виробництва боєприпасів відповідно до встановлених мобілізаційних завдань. У іншому випадку здійснюються заходи з придбання боєприпасів із-за кордону.

Для забезпечення потреб збройних Сил у боєприпасах у ході операцій відбувається поповнення боєприпасами до потрібного рівня, накопичення боєприпасів для проведення подальших операцій Об'єднаних сил.
Формування запасів боєприпасів пов'язане з наявними спроможностями $з$ їх придбання (при самостійному виробництві або закупівлі за кордоном), які можуть бути відсутні або вкрай обмежені. Формування спроможностей придбання відбувається у мирний час. На малюнках 1, 2 показані відповідно процеси розвитку спроможностей 3 забезпечення боєприпасами при самостійному виробництві в мирний та воєнний час.

Обсяги у потребах Збройних Сил у боєприпасах у цих процесах значно відрізняються. Тому, як правило, на воєнний час передбачається створення додаткових (мобілізаційних) виробничих потужностей.

Розглянемо процес розвитку спроможностей 3 забезпечення боєприпасами при самостійному виробництві в мирний час (мал. 1) та критерій оцінки його ефективності.

Таблиця 1. - Інформаційно-логічна модель процесу забезпечення потреб збройних Сил боєприпасами

\begin{tabular}{|c|c|c|c|c|c|c|}
\hline \multirow{2}{*}{ Суб'єкти } & \multirow{2}{*}{ Мирний час } & \multicolumn{5}{|c|}{ Заходи особливого періоду } \\
\hline & & \multicolumn{3}{|c|}{ Час мобілізації } & \multicolumn{2}{|c|}{ Воєнний час } \\
\hline \multirow[b]{2}{*}{ 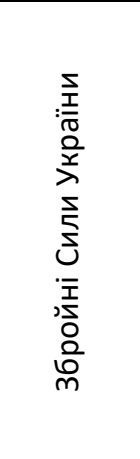 } & \multirow[b]{2}{*}{\begin{tabular}{|c|} 
Уточнення \\
завдань і \\
функцій, \\
розвиток, \\
підготовка і \\
підтримання на \\
належному рівні \\
боєздатності, \\
планування \\
застосування, \\
бойова \\
підготовка
\end{tabular}} & \multicolumn{3}{|c|}{ Стратегічне розгортання Збройних Сил } & \multicolumn{2}{|c|}{ Операції Об'єднаних Сил } \\
\hline & & $\begin{array}{c}\text { Доукомплектува } \\
\text { ння військ до } \\
\text { штатів воєнного } \\
\text { часу. } \\
\text { Бойове } \\
\text { злагодження }\end{array}$ & \begin{tabular}{|c|} 
Оперативне \\
розгортання \\
Збройних Сил
\end{tabular} & \begin{tabular}{|c|} 
Розгортання \\
стратегічних \\
резервів
\end{tabular} & $\begin{array}{c}\text { Оборонна } \\
\text { операція, } \\
\text { Забезпечення } \\
\text { досяжного рівня } \\
\text { вогневого } \\
\text { ураження } \\
\text { противника }\end{array}$ & $\begin{array}{c}\text { Контрнаступальна } \\
\text { операція, } \\
\text { Забезпечення } \\
\text { досяжного рівня } \\
\text { вогневого } \\
\text { ураження } \\
\text { противника }\end{array}$ \\
\hline \multirow{3}{*}{ 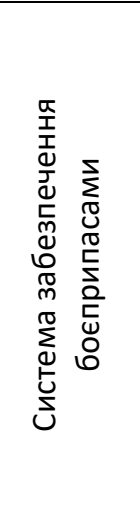 } & \multicolumn{4}{|c|}{ Накопичення боєприпасів для потреб ЗС (за необхідністю) } & \multicolumn{2}{|c|}{$\begin{array}{c}\text { Забезпечення потреб ЗС у } \\
\text { боєприпасах }\end{array}$} \\
\hline & $\begin{array}{c}\text { Постачання } \\
\text { боєприпасів, } \\
\text { оновлення } \\
\text { боєприпасів, їх } \\
\text { утилізація. }\end{array}$ & Військових & Оперативних & Стратегічних & \begin{tabular}{|c|} 
Поповнення \\
боєприпасами до \\
потрібного рівня, \\
накопичення \\
боєприпасів для \\
проведення \\
контрнаступальної \\
операції
\end{tabular} & $\begin{array}{c}\text { Поповнення } \\
\text { боєприпасами до } \\
\text { потрібного рівня, } \\
\text { накопичення } \\
\text { боєприпасів для } \\
\text { проведення } \\
\text { подальших } \\
\text { операцій ОС }\end{array}$ \\
\hline & & \multicolumn{3}{|c|}{$\begin{array}{c}\text { Переведення підприємств боєприпасної } \\
\text { галузі на виробництво боєприпасів } \\
\text { відповідно до мобілізаційних завдань }\end{array}$} & & \\
\hline
\end{tabular}

Аналізуючи потреби Збройних Сил і наявні спроможності самостійного виробництва мирного часу можна провести оцінку ефективності (ступеня) задоволення потреб мирного часу $\mathrm{E}_{3 \mathrm{M}}^{\mathrm{M}}$ як співвідношення кількості вироблених боєприпасів $i$-ї номенклатури $M_{i}^{\mathrm{M}}$ 
до потрібної $N_{i}^{\mathrm{MЧ}}$ :

$$
\mathrm{E}_{3 \mathrm{BY}}^{\mathrm{MU}}=\frac{M_{i}^{\mathrm{MU}}}{N_{i}^{\mathrm{MU}}} .
$$

у ідеальному випадку це співвідношення повинно дорівнюватися одиниці або $100 \%$.

При менших значеннях формуються та діють відповідні довгострокові, середньо-строкові та короткострокові програми розвитку спроможностей самостійного виробництва. На ці заходи потрібно відповідне фінансування та встановлені терміни набуття спроможностей 3 виробництва боєприпасів, які повинні наближатись до потреб мирного часу:

$$
M_{i}^{\mathrm{M \Psi}} \rightarrow N_{i}^{\mathrm{M \Psi}} .
$$

Тоді, ефективність спроможностей 3 забезпечення потреб у боєприпасах при самостійному виробництві В мирний час

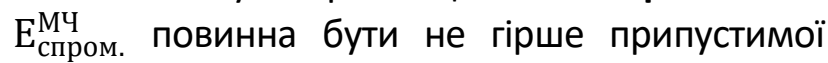

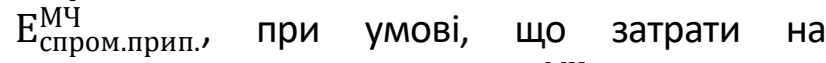

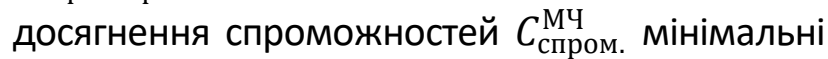
$C_{\text {спром. min }}^{\mathrm{M \Psi}}$

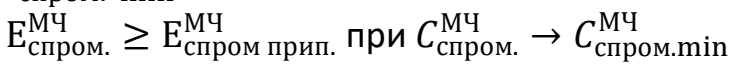

$\begin{array}{ccr}\text { Розглянемо } & \text { процес } & \text { розвитку } \\ \text { спроможностей } & 3 & \text { забезпечення } \\ \text { боєприпасами } & п р и & \text { самостійному }\end{array}$
виробництві в воєнний час, що наведений на малюнку 2, та критерій оцінки його ефективності. Процес схожий з попереднім процесом. Аналізуючи потреби Збройних Сил у боєприпасах на воєнний час і наявні спроможності самостійного виробництва можна провести оцінку ефективності (ступеня) задоволення потреб збройних Сил у боєприпасах на воєнний час $\mathrm{E}_{\text {спром. як }}^{\text {ОП }}$ співвідношення кількості вироблених боєприпасів $i$-ї номенклатури $M_{i}^{\text {ОП }}$ до потрібної $N_{i}^{\text {OП: }}$

$$
\mathrm{E}_{\text {спром. }}^{\text {ОП }}=\frac{M_{i}^{\text {ОП }}}{N_{i}^{0 \Pi}}
$$

На заходи до створення спроможностей забезпечення боєприпасами воєнного часу потрібно також відповідне фінансування та встановлені терміни набуття спроможностей 3 виробництва боєприпасів, які повинні наближатись до потреб у боєприпасах на воєнний час: $M_{i}^{\mathrm{BU}} \rightarrow N_{i}^{\mathrm{B \Psi}}$.

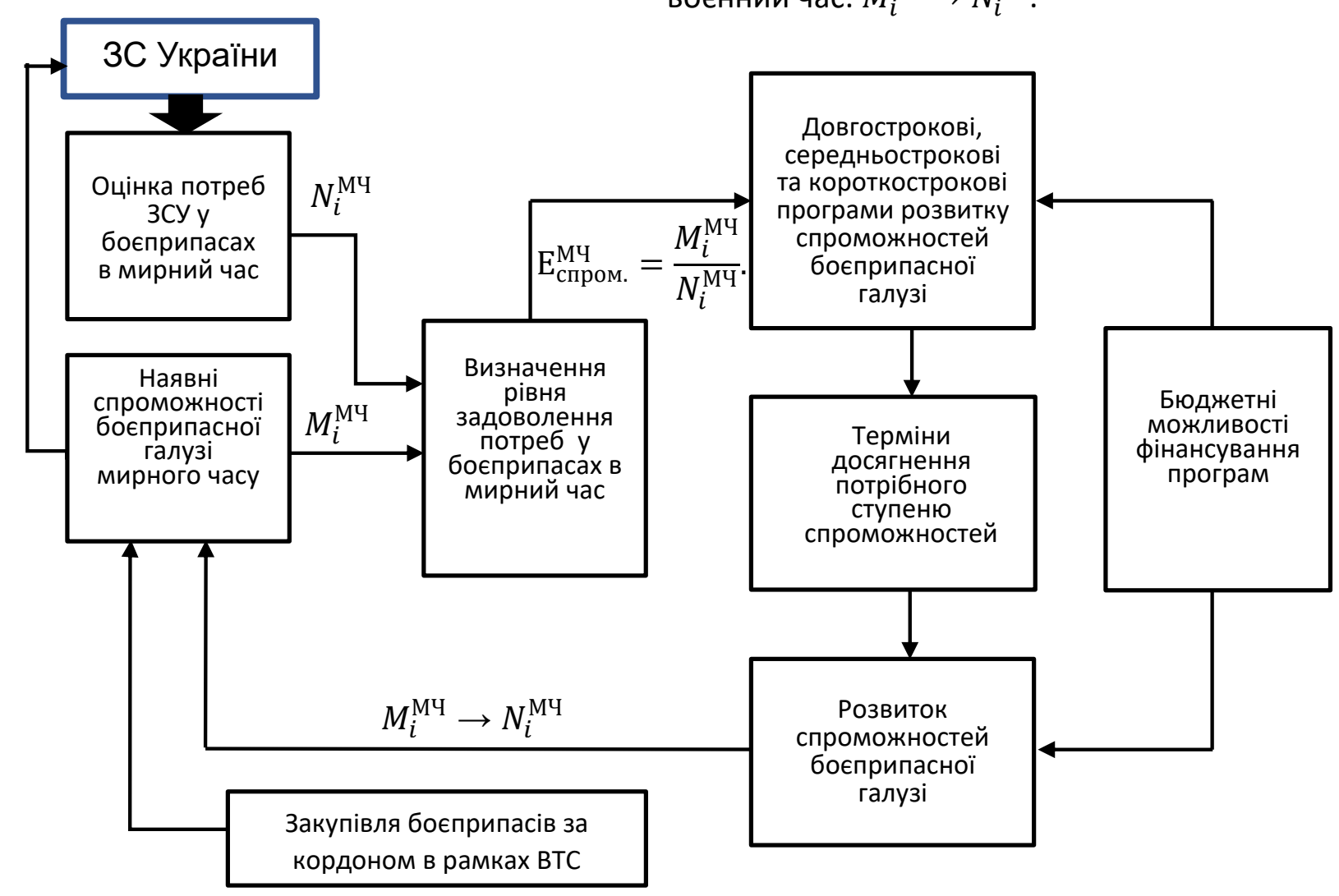

Мал. 1 - Процес набуття потрібних спроможностей з забезпечення боєприпасами при самостійному виробництві в мирний час 


\begin{tabular}{|c|c|c|}
\hline Розглянемо & розвитку & кількості вироблених \\
\hline спроможностей & забезпечення & номенклатури $M_{i}^{\text {OП }}$ \\
\hline боєприпасами при & самостійному & потрібної $N_{i}^{\text {OП: }}$ \\
\hline $\begin{array}{l}\text { виробництві в воєнний час, що } \\
\text { рисунку } \quad 2, \quad \text { та критерій }\end{array}$ & $\begin{array}{l}\text { наведений на } \\
\text { оцінки його }\end{array}$ & $\mathrm{E}_{\text {спром. }}^{\text {OП }}=\frac{M_{i}^{\text {OП }}}{N_{i}^{\text {OП }}}$ \\
\hline $\begin{array}{l}\text { ефективності. Процес схожий } \\
\text { процесом. Аналізуючи потреби }\end{array}$ & $\begin{array}{l}3 \text { попереднім } \\
\text { Збройних Сил }\end{array}$ & $\begin{array}{l}\text { На заходи до створення спроможностей } \\
\text { забезпечення боєприпасами воєнного часу }\end{array}$ \\
\hline $\begin{array}{l}\text { У боєприпасах на воєнний } \\
\text { спроможності самостійного }\end{array}$ & $\begin{array}{l}\text { час і наявні } \\
\text { виробництва }\end{array}$ & $\begin{array}{l}\text { потрібно також відповідне фінансування та } \\
\text { встановлені терміни набуття спроможностей }\end{array}$ \\
\hline $\begin{array}{l}\text { можна провести оцінку } \\
\text { (ступеня) задоволення потреб }\end{array}$ & $\begin{array}{l}\text { ефективності } \\
\text { Збройних Сил }\end{array}$ & $\begin{array}{l}3 \text { виробництва боєприпасів, які повинні } \\
\text { наближатись до потреб у боєприпасах на }\end{array}$ \\
\hline у боєприпасах на воєнний & час $\mathrm{E}_{\text {спром. }}^{\text {ОП }}$ & воєнний час: $M_{i}^{\mathrm{BЧ}} \rightarrow N_{i}^{\mathrm{BЧ}}$ \\
\hline
\end{tabular}

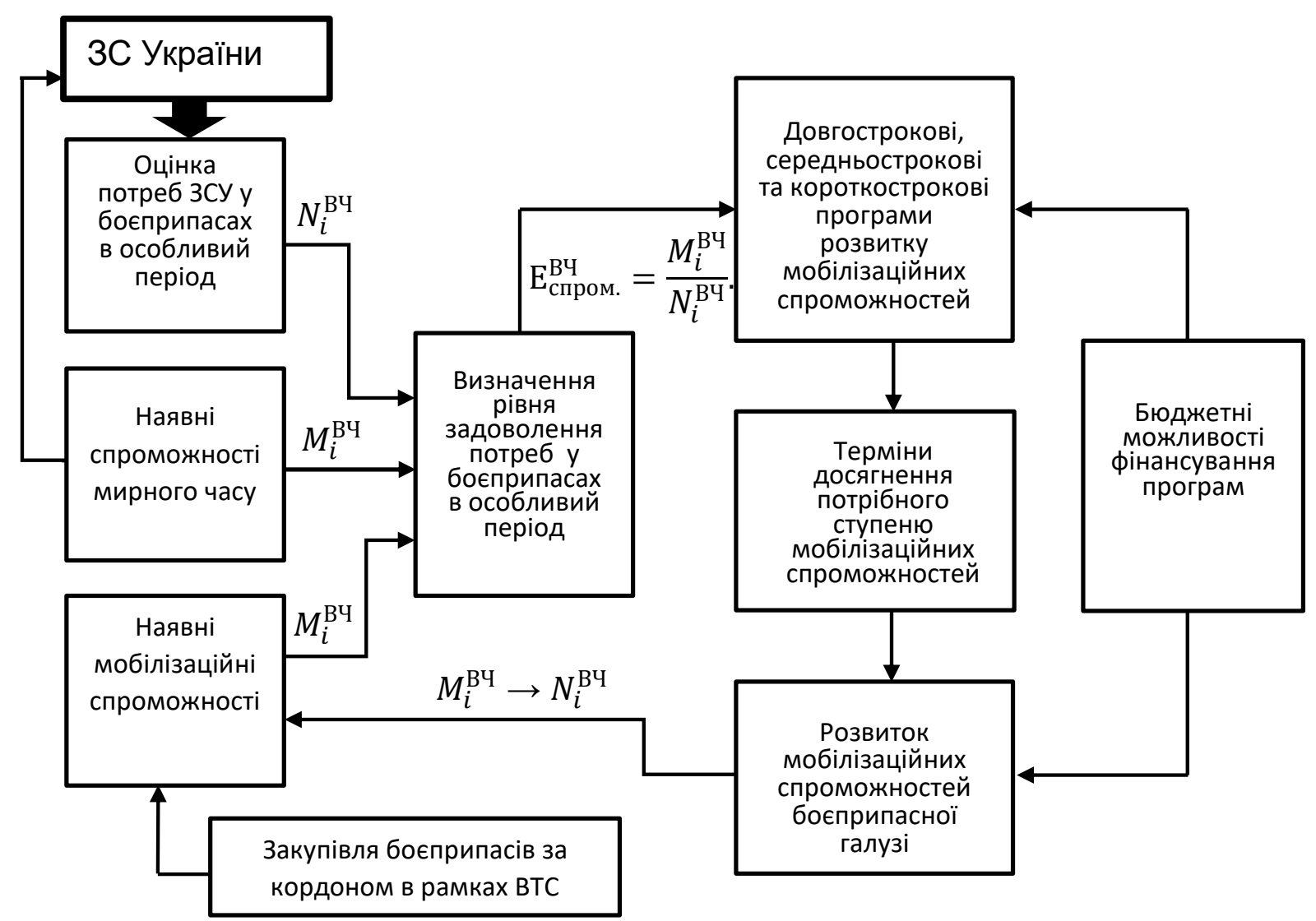

Мал. 2 - Процес набуття потрібних спроможностей забезпечення боєприпасами при самостійному виробництві у воєнний час

\section{Ефективність} спроможностей забезпечення потреб у боєприпасах в воєнний час повинна бути не гірше припустимої

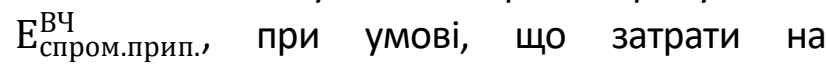

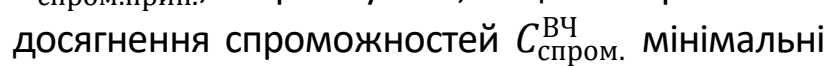
$C_{\text {спром. } \min }^{\text {BЧ }}$

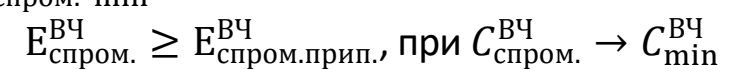

Значення припустимого рівня ефективності повинно бути визначено методом експертних оцінок та затверджено нормативно.

До набуття потрібних спроможностей, як для мирного часу, так і для воєнного часу можливо проведення закупівлі боєприпасів за кордоном.

На підставі аналізу класичної шкали Харрингтона, запропонована скорочена за рівнями шкала оцінки ефективності задоволення потреб Збройних Сил у боєприпасах, що наведена у таблиці. 2. 
Таблиця 2 - Шкала оцінки ефективності задоволення потреб Збройних Сил у боєприпасах

\begin{tabular}{|c|c|}
\hline Рівень ефективності & Значення показника, $\mathrm{E}_{36 п}$ \\
\hline висока & $\mathrm{E}_{\text {збп }} \geq 0,63$ \\
\hline середня & $0,63>\mathrm{E}_{\text {збп }}>0,37$ \\
\hline низька & $\mathrm{E}_{\text {збп }} \leq 0,37$ \\
\hline
\end{tabular}

Таким чином, запропонований методичний підхід дозволяє наглядно зв'язати заходи Збройних Сил, що відбуваються як у мирний час так і у воєнний час з діями, що повинні відбуватись у системі забезпечення Збройних Сил боєприпасами для задоволення їх потреб.
Такий підхід дозволяє організувати процес формування спроможностей забезпечення потреб Збройних Сил боєприпасами, як за рахунок самостійного виробництва, так і шляхом закупівлі боєприпасів за кордоном.

\section{Висновки}

1. Питання створення запасів боєприпасів не втратило своєї актуальності і в сучасних умовах. Подібні запаси створюються у всіх арміях провідних країн світу.

2. Особливої уваги в питаннях впровадження оборонного планування на основі спроможностей потребують функціональний аналіз усіх вимог до існуючих та необхідних спроможностей та визначення взаємозалежності сил і засобів.

3. Для проведення аналізу відповідності між завданнями, що вирішують Збройні Сили України, та заходами щодо забезпечення потреб Збройних Сил боєприпасами в мирний час і в воєнний час, пропонується використовувати інформаційно-логічну модель зміст якої відображає рішення, що приймаються у системі забезпечення боєприпасами стосовно створення певних видів запасів боєприпасів та їх відповідності завданням Збройних Сил.

Заходи набуття потрібних спроможностей виробництва боєприпасів як у мирний час, так і у воєнний час потребують ретельного планування та виконання для забезпечення можливості набуття Збройними Силами України потрібних спроможностей при проведенні операцій.

\section{Список використаних джерел}

1. НАТО, використання сценаріїв довгострокового планування оборони. - URL: http://www.plausiblefutures.com/55074

2. Manual for the Operation of the Joint Capabilities Integration and Development System (JCIDS). № 3170.01I. 12 February 2015. Joint Staff, 2015, 416 p.

3. Рекомендації з оборонного планування на основі спроможностей в Міністерстві оборони України та Збройних Силах України : затверджено Міністром оборони України, 12 червня 2017 року / Міністерство оборони України (Департамент воєнної політики, стратегічного планування та міжнародного співробітництва Міністерства оборони
України). - К. : МОУ, 2017. - 29 с.

4. Іващенко А. М., Павліковский А. К., Сивоха И. М. Концепція оборонного планування на основі розвитку спроможностей: проблеми впровадження. URL: http://znpcvsd.nuou.org.ua/article/view/125516/1199 73.

5. Рада $з$ досліджень та технологій НАТО: група 3 досліджень, аналізу та моделювання (SAS) // Довідник 3 довгострокового оборонного планування, 2001.

URL: www.dtic.mil/dtic/tr/fulltext/u2/a414193/p df.

6. Руснак І. С. Оборонне планування на основі спроможностей: особливості 
перспективи впровадження/ І. С. Руснак, А.

Г. Петренко, А. В. Яковенко, І. М. Романюк, В. Д. Кохно // Наука і оборона. - 2017 - №2.

- C. 3-10.
7. Захаров А. Н. Операция “Лис пустыни". Развитие стратегии и оперативного искусства / А.Н. Захаров // Военная мысль. - 1999. - № 5. - С. 67-70.

\title{
Об управлении возможностями обеспечения потребностей вооруженных сил боеприпасами
}

\author{
Евгений Косарецький ${ }^{*} 1$ А; Анатолий Павликовский ${ }^{2}$; \\ Олег Бондаренко ${ }^{4}$; Михаил Лаврук 5 А \\ * Corresponding author: ${ }^{1}$ адъюнкт, e-mail: geka1982@i.ua, ORCID: 0000-0001-9601-8544 \\ 2 кандидат военных наук, доцент, начальник Центра военно-стратегических исследований, e-mail: geka1982@i.ua, ORCID: 0000-0002-0637-368X \\ ${ }^{3}$ кандидат военных наук, доцент, доцент кафедры, e-mail: hunbinkonstantin65@gmail.com \\ ${ }^{4}$ кандидат военных наук, доцент, доцент кафедры, e-mail: dinamo_kiev7@ukr.net, ORCID: 0000-0001-5360-0120 \\ ${ }^{5}$ старший преподаватель кафедры, e-mail: tkachivan9@gmail.com \\ А Национальный университет обороны Украины имени Ивана Черняховского, пр-кт Воздухофлотский, 28, г. Киев, 03049, Украина

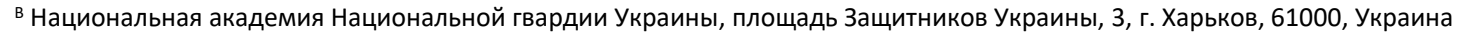 \\ с Институт государственного управления и научных исследований по гражданской защите, г. Киев, 02000, Украина
}

\begin{abstract}
Аннотация
В статье осуществлен анализ задач, выполняемых Вооруженными Силами Украины и мер по обеспечению боеприпасам Вооруженных Сил Украины в мирное и в военное время. Целью исследования является анализ соответствия между задачами, которые решают Вооруженные Силы Украины, и запасами боеприпасов, предназначенных для обеспечения войск при выполнении ними задач. На основании систематизации литературных источников и подходов к решению проблемы обеспечения Вооруженных Сил Украины боеприпасами выяснено, что при любых условиях обстановки Вооруженные Силы должны обеспечить сдерживание вооруженной агрессии против Украины и предоставить им отпор, осуществлять охрану воздушного пространства государства $и$ подводного пространства в пределах территориального моря Украины в случаях, определенных законодательством Украины, а также участвовать в мероприятиях, направленных на борьбу с терроризмом. Методическим инструментарием проведенного исследования стали анализ, синтез, декомпозиция, опыт ведения боевых действий на Востоке Украины. В исследовании рассмотрены процессы получения нужных возможностей обеспечения боеприпасами Вооруженных Сил Украины в мирное и военное время. Предложенные показатели и критерии оценки эффективности возможностей обеспечения потребностей Вооруженных Сил боеприпасами. Предложенная информационно-логическая модель процесса обеспечения Вооруженных Сил боеприпасами в мирное время и в военное время, которая дает наглядное представление соотношения задач, выполняемых Вооруженными Силами Украины и мер обеспечения боеприпасам Вооруженных Сил Украины в мирное и в военное время. Модель целесообразно применять при поддержке принятия решений и организации мер обеспечения Вооруженных Сил боеприпасами. Результаты проведенного исследования могут быть полезными для ученых и управленцев, изучающих проблематику всестороннего обеспечения боеприпасами Вооруженных Сил Украины во время проведения ими операций по сдерживанию вооруженной агрессии.
\end{abstract}

Ключевые слова: Вооруженные Силы, способность обеспечения, информационнологическая модель, мирное время, военное время, боеприпасы, обеспечение.

\section{Regarding the management of the capabilities to meet the needs of the armed forces with ammunition}




\title{
Yevhenii Kosaretsky * 1 A; Anatoliy Pavlikovsky 2 A; Kostiantyn Hunbin ${ }^{3 \text { B; }}$ Oleh Bondarenko ${ }^{4}$ C; Michael Lavruk 5 A \\ Corresponding author: ${ }^{1}$ PhD student, e-mail: geka1982@i.ua, ORCID: 0000-0001-9601-8544 ${ }^{2}$ Candidate of Military Sciences, Associate Professor, Head of the Center, e-mail: geka1982@i.ua, ORCID: 0000-0002-0637-368X ${ }^{3}$ Candidate of Military Sciences, Associate Professor, Associate Professor of the Department, e-mail: hunbinkonstantin65@gmail.com ${ }^{4}$ Candidate of Military Sciences, Associate Professor, e-mail: dinamo_kiev7@ukr.net, ORCID: 0000-0001-5360-0120 ${ }^{5}$ Lecturer of the department, e-mail: tkachivan9@gmail.com \\ A National Defence University of Ukraine named after Ivan Cherniachovskyi, 28, Povitroflotsky, ave, Kyiv, 03049, Ukraine ${ }^{B}$ National Academy of the National Guard of Ukraine, 3, Defenders of Ukraine Square, Kharkiv, 61000, Ukraine ${ }^{\mathrm{C}}$ Institute of public administration and research in civil protection, Kyiv, Ukraine
}

\begin{abstract}
The article analyzes the tasks performed by the Armed Forces of Ukraine and measures to provide ammunition to the Armed Forces of Ukraine in peacetime and in wartime. The purpose of the study is to analyze the correspondence between the tasks of the Armed Forces of Ukraine and ammunition stocks. Based on the systematization of literature sources and approaches, it was clarified that under any circumstances, the Armed Forces must ensure the deterrence of armed aggression against Ukraine, as well as participate in measures to combat terrorism. The methodological tools of the study were analysis, synthesis, decomposition, experience of hostilities in eastern Ukraine. The study examines the processes of acquiring the necessary capabilities to provide ammunition to the Armed Forces of Ukraine in peacetime and in wartime. Indicators and criteria for assessing the effectiveness of capabilities to meet the needs of the Armed Forces with ammunition are proposed. The information-logical model of the process of providing the Armed Forces with ammunition in peacetime and in wartime is proposed, which gives a clear idea of the ratio of tasks performed by the Armed Forces of Ukraine and measures to provide ammunition to the Armed Forces of Ukraine in peacetime and wartime.
\end{abstract}

Keywords: Armed Forces, security capability, information-logical model, peacetime, wartime, ammunition, software.

\section{References}

1. NATO, use of long-term defense planning scenarios. Available from: http://www.plausiblefutures.com/55074

2. Manual for the Operation of the Joint Capabilities Integration and Development System (JCIDS). № 3170.01I. 12 February 2015. Joint Staff, 2015, 416 p.

3. Recommendations on capability-based defense planning in the Ministry of Defense of Ukraine and the Armed Forces of Ukraine: approved by the Minister of Defense of Ukraine, June 12, 2017 / Ministry of Defense of Ukraine (Department of Military Policy, Strategic Planning and International Cooperation of the Ministry of Defense of Ukraine). Kyiv: MOY, 2017. 29 p.

4. Ivashchenko A. M., Pavlikovsky A. K., Sivokha I. $M$. The concept of defense planning based on capability development: problems of implementation. Available from: http://znpcvsd.nuou.org.ua/article/view/125516/11997 3.

5. NATO Research and Technology Council: Research, Analysis and Modeling Group (SAS) // Handbook on Long-Term Defense Planning, 2001. Available at: www.dtic.mil/dtic/tr/fulltext/u2/a414193/pdf. 6. Rusnak I. S., Petrenko A. G., Yakovenko A. V., Romanyuk I. M., Kokhno V. D. (2017) Kokhno Defense planning based on capabilities: features and prospects of implementation. Science and defense. 2017 №2. P. 3-10.

7. Zakharov A. N. (1999) Operation "Desert Fox". Development of strategy and operational art. Military Thought. № 5. P. 67-70 